\title{
Modern Languages Transition from Primary to Secondary School: The German Pupils' Voice
}

\author{
Gary N. Chambers \\ University of Leeds, $U K$
}

\begin{abstract}
Transition from primary to secondary school poses a range of challenges for children, parents and teachers. Transition in relation to modern languages, given the subject's comparatively new place on the timetables of primary schools in England, raises its own specific issues. The purpose of this British Academy funded study was to find out what pupils in Saxony-Anhalt, Germany, thought about transition. The same 34 pupils were interviewed in Year 4 (age 10) at primary school and again in Year 5 (age 11) at secondary school. They reported their enjoyment of English lessons at both primary and secondary school, although work got harder following transition. Provision was consistent across primary and secondary schools. English was the language taught in all primary schools. Teachers had undergone English-specific training, including time spent in England. Regular assessment ensured that pupils were aware of their attainment in English. Participation in Open Days at the secondary school led to primary pupils feeling comfortable about the transfer to secondary school. Well managed though transition appeared to be, this study identified some areas where improvements could be made, for example, in relation to communication and collaboration between primary and secondary colleagues.
\end{abstract}

\section{Introduction}

Few studies have reported on the views of the end-users of transitional arrangements for modern languages, that is, the pupils. This study in SaxonyAnhalt was broadly informed by a parallel study [1] carried out in the north of England. Pupils there were asked what they thought about their primary modern foreign languages (PMFL) experience and transition to secondary school. Pupils in Saxony-Anhalt were given the same opportunity to share their thoughts on how schools' practices in relation to transition impacted on their foreign language learning experience. What they said offers to teachers and policy makers some pointers on how primary and secondary schools might work together better to enhance the transitional experience of pupils not only in this German province but, arguably, other countries too.

\section{Background}

Getting transitional arrangements right are key to providing pupils new to secondary school an anxietyfree, happy start in their new learning context [2]. Partly because of its relatively recent advent to primary schools in England, transition in relation to primary modern foreign languages (PMFL) brings challenges of its own (e.g. [3]). This research looked abroad in search for guidance from a country with greater experience in this area. It was hoped that lessons could be learned which might be transferable to the English context where (the latest incarnation of) PMFL is still in its infancy.

Various studies [3], [5], [6], [7], have identified ongoing languages-related transitional issues requiring attention in England (and indeed elsewhere: [8], [9], [10]): insufficient communication between secondary schools and their feeder primary schools; absence of collaboration; little consistency across primary schools relating to language/s taught, number of lessons, teaching activities; pupils and parents having little awareness of pupils' attainment in PMFL; starting the language learning experience afresh in the secondary school, with little acknowledgement given to learning at primary school.

Chambers [4] conducted a qualitative study in Saxony-Anhalt, Germany, which focussed on the views of secondary school teachers on pupils' transition from primary school to secondary school, with particular reference to modern languages, in this research context, English. There was much to commend. Primary and secondary school teachers used one of two textbooks approved by the Kultusministerium (ministry of Education for Saxony-Anhalt) as well as a common scheme of work, again approved by the Kultusministerium. This ensured consistency in relation to what was taught and the methods used to teach it. Assessment of pupils in primary schools informed a Zeugnis (report) which was passed on to the relevant secondary 
school. Saxony-Anhalt, in spite of its position as the poorest Land (province) in Germany, invested heavily in the initial and continuing training of its primary school teachers to teach English. This ensured a year-on-year increase in the number of specialist English teachers in primary schools.

Interestingly, however, Saxony-Anhalt, in spite of its longer history of teaching PMFL, (it was introduced in 2005), shared some of the problems relating to transition from primary to secondary school as had been identified in England: communication between secondary schools and their feeder primary schools was lacking; there was little evidence of collaboration; although primary schools provided secondary schools with a report with a grade for each pupil's overall attainment in English, there was no detail on particular skills and competences; some secondary school teachers felt that they could not rely on the accuracy of the given grades, and carried out their own diagnosis in the initial weeks of the first year of secondary school.

The research informing this paper gave the pupils in Saxony-Anhalt a voice. What were their perceptions of their English learning experience? What were their views on their transition from primary to secondary school? What could these 10 and 11 year olds tell us which might be useful for the enhancement of provision around transition?

\section{Research questions}

The research team sought pupils' responses to questions around the following overarching areas:

- Does pupil experience in English reflect consistency between primary schools in relation to what is taught and how?

- How do pupils say they prepared for the transition to the secondary school English classroom? Is this sufficient?

- To what extent are pupils aware of their attainment in English as they leave primary school?

- To what extent are pupils aware of any exchange of information between their primary and secondary schools relating to what they have learnt, how they have learnt it and their attainment in English?

- Does pupil enjoyment of English change in the course of years 4 (the final year of primary school in Saxony-Anhalt; most pupils are aged 10) and 5 (the first year of secondary school, when most pupils are aged 11)? If so, in what way? What do pupils think the possible causes of any change might be?
(These research questions areas are very similar to those addressed in the study, referred to above, carried out in the UK [1] around the same time.)

\section{Research design and methodology}

A semi-structured interview, conducted in German, was judged the most appropriate data collection tool (Appendix 1), not least given the age of the pupils (10-11 years). This allowed the interviewer flexibility [13] to adapt the order of questions in line with responses of the individual pupil, whilst, ensuring that all the pre-considered issues were covered.

The purpose of the interview was to gain insights into the pupils' view of their experience of foreign language learning towards the end of primary school and in the first year of secondary school. Whilst the broad areas of questioning were similar, primaryand secondary-specific questions were included. The topics addressed were informed by earlier research and PMFL-specific publications (e.g. [14]). The findings of the earlier study carried out in SaxonyAnhalt on teachers' perspectives [4], were also pertinent. The following issues were discussed with primary interviewees, for example:

- Languages provision (i.e. languages taught; number of lessons); lesson content (i.e. activities and tasks)

- Teaching of English (i.e. who taught the lessons; use of target language etc.)

- Assessment; attainment; recording (including whether pupils were conscious of their attainment and how they were progressing)

- Preparation for transfer to secondary school (i.e. what transitional links did the primary school have with the secondary school; whether Open Evenings were offered; whether English-specific information and activities were provided; whether primary pupils felt anxious at the prospect of transferring to secondary)

- Likes and dislikes re: English (i.e. whether they enjoyed languages lessons and what factors impacted on this)

Under each heading were possible sub-questions, in the event of these being needed (Appendix 1.)

To test its fitness for purpose, the interview schedule was piloted with three native German pupils aged 10,11 and 13, relatives of the appointed research assistant (RA), also a native speaker of German. This led to some small changes to the wording of a small number of questions.

The RA used local knowledge to identify a convenience sample [15] of schools in Saxony- 
Anhalt, exploiting of the RA. He then applied to the Kultusministerium for permission to approach the schools. Once this had been granted, he wrote to the headteachers of the schools, informing them about the purpose and nature of the research and inviting them to identify pupils to be the interview subjects. This produced a convenience sample [15] of nine primary schools for the first phase of data collection (see below) and six secondary schools for phase 2 . (See Appendix 2.)

The purposive interviewee sample [15] consisted of 34 pupils (14 boys; 20 girls). Headteachers had selected them based on their willingness to participate, their perceived ability to answer questions clearly and fully. Parental approval was a key criterion. Pupils, parents and headteachers were thoroughly briefed in advance of each phase of data collection, in writing and again orally just prior to the interviews. They were informed that they could terminate their participation at any time without any need to provide a reason for this.

There were two phases of data collection: February 2013 and January/February 2014. The same pupils were interviewed in each of the two phases which allowed any change or development in their thinking might be identified.

Depending on the detail provided by the pupilinterviewee, interviews lasted between 15 and 20 minutes in each of the two phases.

\section{Analysis of the data}

Interviews were recorded and later transcribed in full. The transcriptions were not translated into English, given that the principal investigator and RA both had native/near native speaker competence in German. Numerous readings of the transcriptions led to the identification of themes [13]. The development of a coding framework followed, which facilitated more detailed interrogation of the data, using the MAXQDA [16] qualitative analysis instrument. This approach to analysis produced some basic descriptive data as well as comparative data relating to differences in findings between schools and between boys and girls.

\section{Limitations}

The study is small-scale. It includes a convenience sample of nine primary schools and six secondary schools from only one Land in Germany. The pupil sample is purposive. This limits generalisability.

A transfer of good policy and/or practice between Saxony-Anhalt and England and other countries with English as the 'first language', (see [11] for a discussion on appropriateness of 'mother tongue', 'first language', 'own language') requires circumspection. In Saxony-Anhalt, Germany as a whole, and most other countries, English has the status of the 'global' language, a prerequisite for advancement in education, career and extremely useful in other aspects of social and work life. The status of foreign languages, however, in England and other countries where English is the 'first language', is lower, with rather less importance given to them [12]. This difference in status and the mindset it engenders, have to be considered carefully in relation to the appropriateness of comparison and transfer of practice, especially where this relates to motivational and attitudinal dimensions.

Despite the above limitations, however, the findings are important to deepening understanding of what pupils think about their PMFL learning experience and the transition to secondary school.

\section{Findings}

\section{Does pupil experience in English reflect any consistency between primary schools in relation to what is taught and how?}

Pupils' responses reflected striking consistency of provision across the sample primary schools. English was the only foreign language taught. Without exception, pupils continued with English in secondary school. Each pupil had two timetabled English lessons of 45 minutes duration per week. When pupils transferred to secondary schools, this increased to five lessons of 45 minutes duration per week.

All primary schools used one of two textbooks (approved by the Kultusministerium) and, following a common scheme of work, also subject to ministry approval, covered the same themes. These included numbers; colours; parts of the body.

Pupils were taught by specialist English teachers on the school staff. In only one of the nine schools was the class teacher also the specialist English teacher. Pupils did not report any English teachers from the local secondary school providing support in lessons (as is often the case in England [1]).

The pupil experience in English lessons was very similar across the primary schools. Teachers ensured that pupils enjoyed a variety of activities such as singing, learning of rhymes, writing and kinaesthetic activities such as cutting and pasting:

Well, Mrs B comes in and we say, "Good morning" to each other. And then she tells us what we are going to do. Mostly we sing in English, we write in English and do some sticking-in. Sometimes we do worksheets. 
(P.29.P. i.e. Pupil 29, interviewed at Primary school. A final ' $S$ ' indicates that the interview was held at Secondary school.)

There was also some evidence of more formal work, for example translation from English into German in the course of which pupils used dictionaries:

We use the textbook, look up the dictionary for English words and also have to translate texts. (P.8.P)

Contrary to the experience of pupils in the research from the north of England [1], pupils in Saxony-Anhalt did not report using computers or video material in primary school, although use of CDs was commonplace:

We have a workbook. Sometimes it includes a CD. There is a square with a CD in it. We have to listen to it and then circle or cross something or draw something out. (P.28.P)

Pupils were set homework tasks following each of their English lessons. They all reported having English tests on a regular basis. In relation to recording and reporting, the study on teachers' perspectives on PMFL in Saxony-Anhalt [4], included some teachers who reported exploiting the European Languages Portfolio [17], designed to allow learners to record their language learning achievements and their experience of learning and using languages. None of the pupils in this sample had any awareness of its use.

A notable feature of English lessons was the dominance of the target language:

Well, my teacher speaks English for the whole lesson. (P2.P)

\section{How are pupils prepared for the transition to the secondary school English classroom and do they feel that this is sufficient and appropriate?}

Local secondary schools organised Open Days and invited primary school pupils to attend, to give them the opportunity to familiarise themselves with the new surroundings and meet some of the teachers and current pupils. Only 3/34 sample pupils did not take advantage of this opportunity: one had been ill; two claimed not to have received the invitation.

The primary pupils engaged in a range of experiences such as a tour of the school and sciencerelated experiments. One pupil particularly enjoyed watching some dancing and a magic show:

Well, you can do dancing there. There's a teacher who does that. A couple of girls danced. And then there was a magic show. I watched it with some friends. And we also saw some classrooms. (P20.P) (5)

English-related activities appeared to have been lacking. One pupil painted an 'English' flag; another saw the English teacher and visited the English classroom. One pupil watched a 'shadow show' which she suspected was in a foreign language but was not sure which one:

I watched the fairy tale of "The three little pigs" as a shadow show - it was in some foreign language, French, I think. (P.13.P)

There was no evidence of anxiety as an issue for any of the primary pupils. All of the sample were looking forward to the move to their new school. They knew that they would be in the company of others from their primary school and welcomed the prospect of making new friends, experiencing new subjects and enjoying the new learning environment:

My brother told me that there was a big playground. Half of the pupils in my class are going there too and they include my best friends. I'm looking forward to it. (P8.P)

What they had also learned from others, however, was that the amount and degree of difficulty of work was going to move up a level:

Yes, it will be harder, because, so far as I know, we'll have to speak English all of the time. And because we'll also have more homework there. (P.12.P)

Three girls foresaw this taking the form of more autonomous learning from the pupils and rather less involvement of the teacher:

We might not do so much with the teacher; we might have to work on our own. (P.6.P)

One boy's conversation with his older brother led to a minor worry that his new English teacher might be a little more abrupt than his current primary teacher:

For example, they'll just come in and speak English right away. They might just say: "Julian - translate!" (P.13.P)

To what extent are pupils aware of any exchange of information between their primary and secondary schools relating to what they have learnt, how they have learnt it and their attainment in English?

Having made the move to secondary school, just under half of the sample (15/34) reported an awareness of their secondary school English teachers having knowledge of the ground which had been covered in the subject in primary school. How the teachers dealt with this knowledge varied. Some made an immediate start on fresh material:

We moved on immediately. (P.4.S) 
Others carried out some diagnostic activities:

Yes, first of all we went over everything again, so that they know what we can do. (P.12.S)

Well, at the beginning we repeated loads of stuff, so that we were all at the same level. (P.22.S)

Twelve pupils $(n=34)$ reported no awareness of their teachers' acknowledgement of primary school English learning and had simply started afresh:

No, not really. We started pretty much from the beginning again. (P.7.S)

Most pupils (20/34) identified an approach in secondary school to lesson content and teaching methods similar to that in primary school:

Yes. We're doing the time, which we also covered at primary school and lots of things which are the same. (P.1.S)

A typical English lesson is like this: we say hello to each other. Then we learn something new or we write out some vocabulary. Then at the end we always sing a song, an English song. (P.9.S)

Of the remaining pupils $11 / 34$ saw distinct differences between the primary and secondary school English lessons:

In primary school we always sang a song, but not here. We wrote out vocabulary but not now. Really, everything has changed. (P.3.S)

In general terms, although the English lessons took broadly the same form at secondary school as at primary, the pupils' predictions regarding the increased amount and heightened degree of difficulty of work was confirmed:

Well, we start with greetings and then we do some work from the textbook and read through some texts. You can get marks for this. Then we learn some new vocabulary and copy this into our exercise book; we set it out by vocabulary, sentences, worksheets etc. (P.18.S)

A typical feature reported widely by secondary interviewees was the increase in the amount of English used by the teacher and by pupils::

Yes. Mrs K, my English teacher, she uses more and more English. She tries to speak more and more English to us. (P.2.S) (19)

Yes, our English teacher speaks English only. Actually, we only speak English. (P4.S)

More vocabulary, more homework, more grammar, more tests and more writing - this was the difference between secondary English and what now appeared to be the more leisurely approach to learning at primary school:
We write up a lot of vocabulary. Then we have to learn it and then they tell us we are going to have a test; we learn for the test which will cover the vocabulary which we have just learned. (P.11.S)

We didn't do vocabulary at primary school. We'd sing or something like that. Here we do lots of vocabulary. I've got a vocabulary note-book here. (P.16.S)

Whilst interviewees felt the challenge of greater demands being placed on them in English, they appreciated that the outcome was an increase in their learning:

We do different tests here. Here we have to write 10 sentences which then get marked. Yes, we learn a lot more. (P.5.S)

Yes, the lessons are different; everything we do is more professional, lots quicker and more organised. We do more. (P.7.S)

Pupils were also conscious of their new teachers' more rigorous approach and tightening of behavioural boundaries:

Our English teacher here is more strict and we do lots more tests. (P.8.S)

When we do tests or suchlike, we are not allowed to talk. We are not allowed to ask any questions. (P.15.S)

The exploitation of electronic hard- and software beyond the CD had not been part of the pupils' primary school English experience. At secondary school, however, they were given access to computers:

On Monday we go to the language laboratory with our proper English teacher and spend the 45 minutes working on the computer. (P.7.S)

Some pupils took the opportunity in the second round of interviews to articulate their preference between primary and secondary school. Interestingly, although they were now experiencing a more demanding, more rigorous and stricter regime, they preferred this over the more relaxed approach in primary school. They enjoyed being challenged and the feeling of making progress.

\section{To what extent are pupils aware of their attainment in English as they leave primary school?}

In the earlier study [4] secondary school teachers in Saxony-Anhalt felt less than happy about the lack of reliable information on pupils' attainment in English from primary school. Each pupil was awarded a single grade for English in their Zeugnis (report) but no further information was provided on their attainment in individual skills or knowledge of 
the cultural dimension. Further, they did not always feel confident that the grade awarded was appropriate. In the light of this, sample pupils were asked whether they felt their teacher had been informed about and therefore knew the level of competence they had brought from primary school.

Nineteen $(n=34)$ pupils were confident that their secondary school English teachers had this information. In spite of this, some of these teachers were reported to have checked for themselves the information provided:

Yes, he certainly looked at my exercise book and saw what sort of difficulties I had, where the others in the class had difficulties and he worked on that more intensively. (P.7.S)

Ten interviewees did not share this confidence. They judged their teachers to have tested their competence at the beginning of the secondary school experience by means of numerous diagnostic tests:

No, because at the beginning we did lots and lots of tests and exercises, without any marks being given. (P.21.S)

Three pupils did not know whether their teachers were aware of their attainment from primary school or not.

\section{Does pupil enjoyment of learning English change in the course of years 4 and 5 ? If so, in what way? What do pupils think the possible causes of any change might be?}

In the first round of interviews carried out in primary school, all of the pupils reported enjoying English lessons. They understood the importance of English; they knew they needed to learn it and indeed wanted to learn it. In round 2 of interviews at secondary school there were few signs of change with 26/34 responding equally positively:

English lessons are good. We learn something new every lesson and we always leave happy. We have nothing to complain about and the teacher doesn't tell us off either. (P.16.S)

Four pupils were now less enthusiastic as they struggled with the heightened degree of difficulty now experienced in the new school ('Because it's difficult.' P.20.S)). One pupil was unhappy with the poor behaviour which was allowed to prevail in secondary English lessons and the boredom experienced as a consequence:

Sometimes, whenever we have Mrs J, the lesson is quite chaotic and then it gets boring; everyone gets punished and we have to write out the whole text. And it gets boring. (P.21.S)
Such criticism, however, was very much the exception to the norm. Primary and secondary pupils reported general satisfaction, and indeed more, with the English learning experience.

\section{Discussion}

Bearing in mind the caveat articulated under 'Limitations' (section 6) relating to difference in status between English in Germany and MFL in the UK and other countries where English is the lingua franca, the discussion which follows addresses the findings in relation to each of the research questions but avoids any comparisons between countries in relation to attitudinal and motivational dimensions.

Pupils in this Saxony-Anhalt-based sample experienced a consistency of provision across all their primary schools, a feature which was found to be lacking in studies based in England [1]; [3]; [6]; [7]; [18]. They reported being taught by teachers with English competence who had been trained to teach English. Their English learning in terms of content and teaching methods was informed by a common scheme of work. This led to a positive impact on pupils' perceptions of the subject and its importance for their future. Similarly, Graham et al., [18] in their UK-based study on pupils making the primary to secondary school transition, concluded that the time allocated to the language, the competence of the teacher and the quality of the training s/he had received, influenced the learners' attitude and motivation and impacted on test scores.

Having one foreign language on offer in primary schools, a set number of lessons per week, with a fixed duration and a common, shared approach to teaching, which has to be centrally approved, is likely to feel alien, perhaps unacceptable, to many teachers in the UK, Ireland and other countries where English is the 'first language'. Their preference may well be freedom of choice to accommodate the circumstances and needs of the local context. Having the chosen MFL permeating the curriculum, as and when appropriate, might be perceived in some schools as a good way of fitting the language into an overcrowded timetable. 'One size fits all' is not a philosophy which is felt to work. Having said that, however, one language, one textbook, one pedagogical approach allows secondary teachers to know what has been taught in primary school and how, the competence brought by pupils to the secondary school and the foundation on which they have to build in the first year of secondary education. This, in theory at least, does much to facilitate a smooth primary-secondary transition in the MFL, in the case of Saxony-Anhalt, English.

An area in which our Saxony-Anhalt colleagues might improve provision relates to Open Days. The 
pupils enjoyed attending these but reported an absence of any English-related activities. Whilst all of the primary school interviewees looked forward to moving to secondary schools, there was a little evidence of concern about the work being harder and the teachers being more strict. Might this concern be alleviated by the inclusion of English-specific activities led by the English teachers and supported by current secondary English pupils? Maybe a question and answer session involving an English teacher and some current pupils would have helped?

Unlike primary pupils in most UK schools (see for example [1]) pupils in Saxony-Anhalt reported undergoing a regular testing regime in English (as they do in all subjects). The results of these tests then inform the grade which they are awarded in their Zeugnis (report). One outcome of this approach is that pupils have a sense of progression. They do not feel any 'sense of stagnation', as identified by Graham and her colleagues [18] in their UK-based study on transition.

In the earlier Saxony-Anhalt study [4], where teachers' views on transition were the focus of interest, some had reported some usage of the European Languages Portfolio [17]. It was a little surprising, therefore, that none of the pupils in this sample had any awareness of it. I suggest that this is an opportunity missed by teachers to go beyond the report with its one grade awarded for English more towards facilitating pupils' reflecting on and recording what they can do well and what they need to work on to improve their English. This would then give teachers in secondary schools a much more complete picture of a pupil's competence at the time of transition.

Most pupils felt that their secondary school English teachers knew what they had learnt at primary school, how they had learnt it and, in most cases, the level of competence to which this had led. The shared scheme of work and textbook, both approved by the Kultusministerium and the Zeugnis (report) helped facilitate this. It came as some surprise, therefore, that as many as 12/34 pupils (still a small number in comparison to UK findings; see, for example, [1]) said that they had started learning English afresh. Others, in the early weeks of secondary school, had undergone a series of diagnostic tests to confirm their level of competence before moving on to new material. Was this the product of secondary school teachers' lack of confidence in primary school teachers' assessment of pupils' competence and/or a professional need to make sure of this for themselves?

A similar line of thinking was prompted by the outcomes of the study on teachers' views of PMFL in Saxony-Anhalt [4]. The Zeugnis (report) serves an important purpose as pupils transfer from primary to secondary but the reaction of teachers to it suggests that it is lacking in the substance needed. More detail on individual skills and competences and/or exploitation of the European Languages Portfolio [17], as suggested above, might help obviate the perceived need for intensive testing at the beginning of the new academic year in the new learning context. That said, there may well always be a cohort of secondary teachers who feel the need to find out for themselves, whether this is based on fragile trust of the judgement of primary school colleagues and/or an innate diligence and conscientiousness. I suggest that better exchange of information, a more secure trust between colleagues and a more sound foundation on which to build at secondary school could well be the outcome of greater collaboration between English teachers in primary and secondary schools. Participating in each others' classes, coteaching, collaboration on Year 4 and Year 5 schemes of work, might well have major pay-off in the form of mutual understanding between colleagues, better shared intelligence and an enhanced transitional experience for pupils.

The sample pupils in Saxony-Anhalt enjoyed English at primary school and this enjoyment was heightened in secondary school. Their enjoyment was not impaired by any perception of work being too demanding (with only one or two exceptions), of too many tests or of only a modest exploitation of technology. What they valued was the feeling of making progress (a finding in line with the work of Graham et al. [18] and Chambers [1]), the product of being challenged and stretched by trained, competent specialist teachers of English, a subject which they saw as important and relevant to their lives.

\section{Conclusion}

There is also much to consider from this study for teachers and policy makers involved in PMFL and transition from primary to secondary school, primarily in Saxony-Anhalt but in other countries too. Consistency of provision across primary schools is important. Focus on one language only would be controversial and unpopular, especially in England, but certainly makes the work of the secondary school to which the primary pupil transfers so much easier. An MFL learning experience driven by an approved, shared and applied scheme of work (e.g. in England that provided by the Qualifications and Curriculum Development Agency, [19]) is key not only to all pupils sharing in the same provision but to secondary schools knowing what pupils have learned, how and to what level. Without this knowledge, transition can be messy and ill-informed and can lead to the pupils' 
prior learning being ignored and their having to make a fresh start in the foreign language. This may then bring into question the very purpose of having PMFL at all.

Primary school pupils need to be taught by teachers appropriately trained in MFL. This calls for adequate resourcing. Saxony-Anhalt has bitten this bullet and provides not only initial teacher education in English for its primary teachers but also continuing professional development for more experienced teachers in post, which may include time spent in England. The place of PMFL in the primary curriculum is regarded as important. It is taken seriously. Adequate provision is therefore made for training, even in the poorest province in Germany. Note of this should be taken by policy makers in other countries.

Appropriate resourcing applies also to time. PMFL needs to be given the timetable space it requires to provide secondary schools with a firm foundation on which to build. Pupils want to feel that they are making progress in their learning. Lesson content as well as the monitoring, assessing and recording of achievement have to facilitate this. Appropriately detailed evidence of pupil achievement has to be provided by primary schools to the secondary schools. Some collaborative work between primary and secondary teachers as well as exploitation of the European Languages Portfolio [17], might well have an important role to play to make this happen in a meaningful, constructive, collegial way.

The pupils in Saxony-Anhalt have spoken. The information they have provided has the potential to enhance MFL provision across primary and secondary schools, not only in Saxony-Anhalt but further afield. Their messages should not be ignored but rather used to stimulate thinking, discussion and action.

\section{References}

[1] Chambers, G.N. "Pupils' perceptions of Key Stage 2 to Key Stage 3 transition in modern foreign languages", in press, 2016.

[2] Evangelou, M., Taggart, B., Sylva, K., Melhuish, E., Sammons, P. and Siraj-Blatchford, I,. What Makes a Successful Transition from Primary to Secondary School? Research Report DCSF-RR019. Department for Children, Schools and Families, London, 2008.

[3] Bolster, A., "Continuity or a fresh start? A case study of motivation in MFL at transition, KS2-3".
Language Learning Journal 37, No.2, pp. 233-254, 2009.

[4] Chambers, G.N., "The Teachers' voice in Saxony-Anhalt: perspectives on transition from primary to secondary school" in Language Learning Journal, http://www.tandfonline.com/doi/full/ 10.1080/09571736.2015.1017519\#abstract, (Access date: 20 March 2015).

[5] Chambers, G.N., "Transition in modern languages from primary to secondary school: the challenge of change" in Language Learning Journal, 42, No.3, pp. 242-260, 2014.

[6] McLachlan, A., "Modern languages in the primary curriculum: are we creating conditions for success?" Language Learning Journal 37, No.2, pp.183-204, 2009.

[7] Hunt, M., Barnes, A., Powell, R. And Martin, C., "Moving on: The challenges for foreign language learning on transition from primary to secondary school", Teaching and Teacher Education, 24, pp.915-926, 2008.

[8] Blondin, C., Candelier, M., Edelenbos, P., Johnstone, R., Kubanek-German, A. and T. Taeschner, Foreign Languages in Primary and PreSchool Education. London: Centre for Information on Language and Teaching Research, 1998.

[9] Hill, K., Davies, A., Oldfield, J. and N. Watson, "Questioning an early start: the transition from primary to secondary foreign language learning", Melbourne Papers in Language Testing 6, 2, pp.2136, 1998.

[10] Rosenbusch, M., "Language learners in the elementary school: investing in the future", Foreign language learning: the journey of a lifetime, ed. R. Donato and R. Terry. Lincolnwood, IL: National Textbook, 1995.

[11] Hall, G. And Cook, G., "Own-language use in language teaching and learning”, Language Teaching, 45, No.3, pp.271-308, 2012.

[12] Chambers G. N., "Pupils' perceptions of the foreign language learning experience", Language Teaching Research, Vol.2, No.3, pp.231-259, 1998.

[13] Wilson, E., School-based Research. A guide for education students. London: Sage, 2009. 
[14] Kirsch, C., Teaching Foreign Languages in the Primary School. London: Continuum, 2008.

[15] Brymon, A., Social Research Methods. Oxford: Oxford University Press, 2008.

[16] MAXQDA (2010 version). http://www.MAXQDA.com

[17] Council of Europe, European Languages Portfolio, 2011. http://www.coe.int/t/dg4/ education/elp/ (Access date: 20 January, 2014).

[18] Graham, S., Marinis, T., Tonkyn, A. and Courtney, L., Primary Modern Languages: the impact of teaching approaches on attainment and preparedness for secondary school language learning. Final Report. University of Reading: Nuffield Foundation, 2014.

[19] Qualifications and Curriculum Development Agency, Schemes of work for KS2 languages, 2007. (http://www.primarylanguages.org.uk/resources/qca_ schemes_of_work.aspx, accessed 25 January, 2015. 


\section{Appendix 1}

\section{Interview Schedule - English version}

\section{The primary school questions}

The headings in italics reflect the main area of questioning. The bullet points are possible questions which could be asked.

\section{Languages provision; lesson content}

- Which foreign language are you learning in school?

- How often do you have English lessons?

- How long does each lesson last?

Teaching of MFL:

- Who teaches these lessons?

- Do you ever have a teacher from the local secondary school?

- Is it always the same one?

- Do this teacher and your usual teacher ever teach together?

- Describe a normal English lesson.

- Does the teacher always speak English?

- Do you ever do tests?

Assessment; attainment; recording:

- Do you know how well you are progressing in English?

- How do you know?

- Have you ever heard of the Languages Ladder?

- Have you ever heard of the European Language Portfolio?

Preparation for transfer to secondary school:

- Have you visited the secondary school you will be attending in Year 5?

- Did you meet any of the English teachers?

- What did they tell you about what you might experience in Year 5?

- Did they ask you about what you are doing at primary school?

- Did you attend a taster English lesson?

- Was it different from what you do in primary school?
Likes and dislikes re: English

- Are you enjoying your English lessons?

- What do you like about them?

- What do you dislike about them?

- Do you look forward to English lessons?

- Would you like to continue with English in future years at this school? Why / Why not?

\section{The secondary school questions}

Language/s provision at secondary school smooth transition from primary school?

- What language are you learning at secondary school?

- Is this the same language that you were learning at primary school?

- How are English lessons different in secondary school?

- Have lessons continued from where you left off at primary school?

- Do you think that your English teacher knows what you did at primary school and has taken this into consideration in her/his teaching?

- What makes you think this?

Perception of teacher's awareness of attainment at primary school? Assessment, recording and reporting at secondary school?

- Do you think that your English teacher knew how well you were doing in English at Primary School?

- What makes you think this?

- Do you do tests in English lessons?

- Are these similar to tests you may have taken at primary School?

Likes / dislikes re: English at secondary school:

- Are you enjoying your English lessons?

- What do you like about them?

- What do you dislike about them?

- Are you enjoying them just as much / more / less than you did at primary school?

- Do you look forward to English lessons? 


\section{Appendix 2}

Table 1. Sample primary schools

\begin{tabular}{|c|c|c|c|c|c|}
\hline School & Description & $\begin{array}{l}\text { Number of } \\
\text { pupils in class }\end{array}$ & $\begin{array}{l}\text { Number of } \\
\text { pupils } \\
\text { interviewed }\end{array}$ & $\begin{array}{l}\text { Number of boys } \\
\text { interviewed }\end{array}$ & $\begin{array}{l}\text { Number of } \\
\text { girls } \\
\text { interviewed }\end{array}$ \\
\hline $\mathbf{A}$ & $\begin{array}{l}\text { Located in city } \\
\text { centre. } 142 \text { pupils. }\end{array}$ & 15 & 4 & 2 & 2 \\
\hline B & $\begin{array}{l}\text { Located in large } \\
\text { village. } 130 \text { pupils. }\end{array}$ & 17 & 5 & 1 & 4 \\
\hline $\mathbf{C}$ & $\begin{array}{l}\text { Located in former } \\
\text { mining village. } 51 \\
\text { pupils. }\end{array}$ & 8 & 5 & 2 & 3 \\
\hline D & $\begin{array}{l}\text { Village location. } 70 \\
\text { pupils. }\end{array}$ & 17 & 4 & 3 & 1 \\
\hline $\mathbf{E}$ & $\begin{array}{l}\text { Located in small } \\
\text { town. Modern } \\
\text { buildings and } \\
\text { facilities. } 92 \text { pupils. }\end{array}$ & 16 & 4 & 2 & 2 \\
\hline $\mathbf{F}$ & $\begin{array}{l}\text { Located in affluent } \\
\text { suburb of city. } 100 \\
\text { pupils. }\end{array}$ & 19 & 4 & 2 & 2 \\
\hline $\mathbf{G}$ & $\begin{array}{l}\text { Located in middle- } \\
\text { class suburb of city. } \\
248 \text { pupils. }\end{array}$ & 19 & 4 & 2 & 2 \\
\hline \multirow[t]{2}{*}{$\mathbf{H}$} & $\begin{array}{l}\text { Located in suburb of } \\
\text { city. } 70 \text { pupils. }\end{array}$ & 13 & 4 & 1 & 3 \\
\hline & & $\begin{array}{l}\text { TOTAL } \\
\text { INTERVIEWED }\end{array}$ & 34 & 15 & 19 \\
\hline
\end{tabular}

Table 2. Sample secondary schools

\begin{tabular}{|c|c|c|c|c|c|}
\hline School & Description & $\begin{array}{l}\text { Number of } \\
\text { pupils attending }\end{array}$ & $\begin{array}{l}\text { Number of } \\
\text { pupils } \\
\text { interviewed }\end{array}$ & $\begin{array}{l}\text { Number of boys } \\
\text { interviewed }\end{array}$ & $\begin{array}{l}\text { Number of } \\
\text { girls } \\
\text { interviewed }\end{array}$ \\
\hline $\mathrm{J}$ & $\begin{array}{l}\text { Grammar school. } \\
\text { City centre location. } \\
\text { Modern facilities. }\end{array}$ & 776 & 10 & 5 & 5 \\
\hline $\mathrm{K}$ & $\begin{array}{l}\text { Grammar school. } \\
\text { Split site; city centre } \\
\text { and edge of city. }\end{array}$ & 1002 & 8 & 5 & 3 \\
\hline $\mathrm{L}$ & $\begin{array}{l}\text { Grammar school. } \\
\text { Edge of city. }\end{array}$ & 955 & 6 & 0 & 6 \\
\hline $\mathrm{M}$ & $\begin{array}{l}\text { Secondary modern } \\
\text { school. Edge of } \\
\text { small town. }\end{array}$ & 350 & 5 & 2 & 3 \\
\hline $\mathrm{N}$ & $\begin{array}{l}\text { Secondary modern } \\
\text { school in small } \\
\text { town. }\end{array}$ & 330 & 3 & 1 & 2 \\
\hline \multirow[t]{2}{*}{$\mathrm{O}$} & $\begin{array}{l}\text { Secondary modern } \\
\text { school. Edge of city. }\end{array}$ & 350 & 2 & 2 & 0 \\
\hline & & $\begin{array}{l}\text { TOTAL } \\
\text { INTERVIEWED }\end{array}$ & 34 & 15 & 19 \\
\hline
\end{tabular}

